\title{
GILLNETS AND CONSERVATION OF THE FRANCISCANA DOLPHIN (PONTOPORIA BLAINVILLEI) IN ARGENTINA: A POLICY PERSPECTIVE
}

\author{
Heidi W. Weiskel ${ }^{1}$, Pablo Bordino² and Alejandro M. Arias ${ }^{2,3}$
}

\begin{abstract}
The franciscana dolphin (Pontoporia blainvillei) is the small cetacean species most frequently caught in inshore gillnet fisheries along the coasts of Argentina, Uruguay and southern Brazil. Within the franciscana's range in the southern Atlantic Ocean, the Cabo San Antonio (CSA) region of the Buenos Aires Province (BAP) in Argentina is an important and understudied location for observations on the species' interactions with the local artisanal gillnet fishery. Through interviews with fishermen, scientists, politicians and officers of the Prefectura Naval Argentina (Argentine Coast Guard, ACG) conducted in 1999 and 2000, this paper investigated the knowledge levels among these different groups about the franciscana and its interactions with the artisanal fishery, in order to develop new policy solutions to the species' high incidental mortality rate in gillnets and failing management regime. The results confirmed the suspected high entanglement rate. The artisanal fishermen were aware of the entanglement problem and reported capture levels, but expressed more concern about their economic stability and the immediate threats posed by overfishing of their target species. The need for coordinated management at the regional, national and international levels emerged as a persistent theme in the interviews, as did a need for education and formal cooperation over living marine resources. Given the current status of fishery and marine mammal laws in Argentina and the South Atlantic region; the widespread use of gillnets; the economics of the artisanal fishery, and the likelihood that sufficient ecological information about the species will not be known or available for many years, several immediate and protective measures to address these needs for the franciscana are suggested.
\end{abstract}

Resumen - El delfín franciscana (Pontoporia blainvillei) es la especie de pequeño cetáceo mas frecuentemente capturada en las pesquerías costeras de redes agalleras a lo largo de las costas del sur de Brasil, Uruguay y Argentina. Dentro de su rango de distribución en el Atlántico Sur, el Cabo San Antonio (CSA) en la Provincia de Buenos Aires (BAP) es una importante y poca estudiada region en relación a la interacción de la especie con la pesca artesanal local. A traves de entrevistas realizadas entre 1999 y 2000 con pescadores, científicos, políticos y Oficiales de la Prefectura Naval Argentina (ACG), este trabajo investigó los niveles de conocimiento de la franciscana entre estos diferentes grupos, con el objetivo de desarrollar nuevas soluciones políticas para la mortalidad incidental de la especie y un régimen de manejo adecuado. Los resultados confirmaron la alta tasa de mortalidad incidental esperada. Los pescadores artesanales se mostraron preocupados por el problema del enmallamiento y reportaron niveles de captura, pero estuvieron mas preocupados por la estabilidad de su situación económica y las inmediatas amenazas producidas por la sobrepesca. La necesidad de manejo coordinado a nivel regional, nacional e internacional emergió como un constante tema durante las entrevistas, como así también la necesidad de educación ambiental y cooperación formal sobre los recursos marinos. Dada la actual implementación de las leyes de pesca y de protección de mamíferos marinos en Argentina y en el Atlántico Sur; el uso de redes agalleras; las economías de las pesquerías artesanales, y la probabilidad que suficiente información ecológica de la especie no será conocida o estará disponible por muchos años, varias acciones inmediatas y protectivas para la franciscana están recomiendas.

Keywords: Pontoporia blainvillei, artisanal fishery, gillnet, bycatch, enforcement, Argentina, management regime, conservation.

\section{Introduction}

The franciscana, also known as the La Plata river dolphin, has restricted distribution to coastal waters of Brazil, Uruguay and Argentina. Its range extends from Itaúnas ( $\left.c a 18^{\circ} 25^{\prime} \mathrm{S}\right)$, Espírito Santo State, southeastern Brazil (Siciliano, 1994), to the Peninsula Valdez (42 $30^{\prime}$ S), Chubut Province, Argentina (Crespo et al., 1998). Its small size and elusive behavior make it one of the most difficult marine mammal species to study. Nevertheless, it is considered to be among the most threatened of the small cetacean species in southern South America (Praderi et al., 1989; Hucke-Gaete, 2000; Secchi et al., in press a).

The franciscana's conservation status is currently a cause of concern for marine scientists and policymakers. It is vulnerable to multiple threats. Chief among them is significant mortality in gillnets, but removal of prey species and biomass in the ecosystem from overfishing, and habitat degradation due to vessel traffic and other anthropogenic activities are also potential threats. Despite numerous studies, beginning in the early 1970's (e.g. Brownell and Ness, 1970; Kasuya and Brownell, 1979; Praderi, 1984; Pinedo et al., 1989; Pinedo, 1991; Secchi et al., 1998; 2001; in press b; Bordino et al., 1999, in press; Ramos et al., 2000; Rodriguez et al., 2002), many data on migratory patterns, the possible existence of sub-populations, abundance, mating behavior, effects of pollution, and interactions with fisheries are still lacking in some areas, making it difficult to establish effective management regimes. The species is currently inadequately protected by legislation in all three countries of its distribution. In the last 15 years, the fishing effort along the Buenos Aires Province (BAP) in Argentina has increased, suggesting the incidental take of the franciscana is also likely on the rise (Crespo et al., 1994; Cappozzo et al., 2000).

The coastal artisanal fishery fleet in Argentina is represented by two different categories of vessels. The "Maritime Artisanal" fleet is characterized by small boats $(<10 \mathrm{~m}$ in length) with outboard motors. The "Rada o Ria" fleet is characterized by bigger boats with internal motors. For this paper, we investigate the "Maritime Artisanal Fleet" and its implications for incidental mortality of the franciscana in the artisanal gillnet fishery in the Cabo San Antonio (CSA) region, examine the legal mechanisms in place for the species in Argentina and internationally, and suggest potential policy solutions to the entanglement and management predicaments. For this paper, we investigated the "Maritime Artisanal Fleet" and its implications for

\footnotetext{
Pew Oceans Commission, 2101 Wilson Boulevard, Suite 550, Arlington, VA 22201, USA. Corresponding author, e-mail: weiskelh@pewoceans.org.

AquaMarina-CECIM, Julian Alvarez 2340 PB2, (1425) Capital Federal, Buenos Aires, Argentina.

Dirección de Recursos Ictículos y Acuícolas, SRNyPA, San Martín $4512^{\circ}$ piso, (1004) Capital Federal, Buenos Aires, Argentina.
} 
incidental mortality of the franciscana in the artisanal gillnet fishery in the Cabo San Antonio (CSA) region. In addition, we examined the legal mechanisms in place for the species in Argentina and internationally, and suggested a list of potential policy alternatives to mitigate the entanglement and management predicaments.

\section{Incidental Take}

The issue of marine mammal bycatch in fisheries has drawn international attention since 1972 (Perrin et al., 1994). In 1995, the Food and Agriculture Organization of the United Nations adopted the non-binding Code of Conduct for Responsible Fisheries, which includes language about minimizing bycatch and modifying gear to the greatest extent practicable. Nonetheless, incidental take numbers have remained at unsustainable levels for many species, including the franciscana. The report of the 1990 International Whaling Commission (IWC) workshop on the incidental mortality of cetaceans in passive fishing nets and traps concluded that wherever gillnets - considered to be possibly the greatest threat to cetaceans worldwide-and cetaceans are found together, at least some cetaceans are entangled (IWC, 1994).

Although several cetacean species are affected by the fisheries in the southern Atlantic Ocean, the franciscana has proven to be exceptionally vulnerable to entanglement in gillnets. In some areas, the franciscana is the species with the highest level of recorded incidental mortality (Praderi et al., 1989; Crespo et al., 1994; Secchi et al., 1997; in press a). In addition, evidence indicates the artisanal fishery may be more dangerous to the franciscana than the larger-scale coastal fisheries (Corcuera, 1994). The franciscana is currently classified as "Data Deficient" in the World Conservation Union (IUCN) 2000 Red List of Threatened Species. However, the IUCN/SSC Cetacean Specialist Group deemed the incidental mortality level of the franciscana to be "dangerously high" (Reeves and Leatherwood, 1994). This group also concluded, as did Perrin and Brownell (1989) and Perrin et al. (1994), that franciscana interactions with gillnets must be carefully monitored.

Pérez Macri and Crespo (1989) published the first paper to focus on the problem of incidental franciscana mortality in Argentine fisheries. Using data from coastal fishermen along the BAP they estimated a minimum annual capture of 340350 dolphins. The study did not examine the maritime artisanal fishery as this activity was incipient at that time. Crespo et al. (1994) published the most comprehensive study to date on the overall situation of marine mammal mortality in Argentine fishing gear. They concluded that the franciscana was the small cetacean species most frequently caught in inshore gillnets along the coasts of Argentina. While it did not include data from the maritime artisanal fishery, it was the first study to refer to the economic and social factors surrounding the fisheries and the first to suggest a link between economic stability and effective resource conservation.

Corcuera et al. (1994) investigated the trawling, purse seine and gillnet commercial fisheries of the two ports of
Necochea and Claromecó in the BAP. They concluded that the annual bycatch of franciscana was high (i.e., in the order of few hundreds) for these two areas and that the artisanal gillnet fishery and the small fishing camps might be more of a threat to the species than any of the other fisheries in Argentina. In a separate study, Corcuera (1994) focused on the effects of the artisanal fishery on the franciscana along the southern coast of the BAP, though did not include the CSA region. Preliminary studies have been done on the artisanal fishery along the CSA (Albareda and Albornoz, 1997; Corcuera et al., 2000), but data remain scarce. An analysis of the overall impact of the artisanal gillnet fishery indicates that the CSA region is likely one of the more dangerous areas for the franciscana (Bordino et al., in press).

\section{Legal Overview}

\section{Argentina}

Provincial and national legislation in Argentina has not been successful in protecting the franciscana from gillnet entanglement. To date, no laws have been enacted to protect it from fishery interactions, and no official management regime has been implemented. All cetaceans found off Argentine coasts are legally covered under the 1974 National Decree N ${ }^{\circ} 1216$, which prohibits direct exploitation. For species such as the franciscana that currently have no commercial value, this legislation is inadequate for addressing the crucial concern of incidental mortality. In 1996, the Secretaría de Desarrollo Sustentable y Política Ambiental de la Nación [the Secretary of Natural Resources and Sustainable Development, (Secretariat)] issued Resolution 351/95. The Resolution is promulgated under the Dirección de Recursos Ictícolas y Acuícolas [Department of Fish and Aquatic Resources]. While the franciscana is listed in Annex I, this resolution addresses marine mammals in captivity, ${ }_{1}^{1}$ and does not provide a mechanism for reducing the incidental mortality caused by particular fisheries.

The National Fishery Law 24.922 from the Secretaría de Agricultura, Ganadería, Pesca y Alimentación de la Nación [Secretary of Agriculture, Livestock, Fishing and Nutrition], was enacted to manage the fishing industries. Out of this January 1998 document came a Fisheries Secretariat; a new Federal Fisheries Agency; species, season and area quotas; a new vessel registration system, and penalties for infraction of the new laws. In addition, one of the specific mandates of the Fisheries Secretariat was to develop a nation-wide campaign to promote fishing and marine resources in Argentine culture. While these laws do not apply to the maritime artisanal fishery, they do have indirect impacts on it.

Regionally, the BAP has its own fisheries law-1994 Law $\mathrm{N}^{\mathrm{o}}$ 11.477. The document encourages the development of all fisheries, and includes a promise of governmental support to provide trucks, freezers, technical accessories and credit line approval for all fishermen, including artisanal fishermen. Such promotion of the industry has not contributed to well-managed fisheries or adequately protected marine mammals in Argentina. 


\section{International}

At the international level, there are various instrumentsthat present potential opportunities to protect the franciscana, although they too have provided little in the way of meaningful conservation. The Convention on Nature Protection and Wild Life Preservation in the Western Hemisphere (Western Hemisphere Convention) (1940) was established to prevent the extinction of any flora or fauna native to the Americas. Specific agreements were made to regulate trade and taking of species needing protection. To date, the franciscana is not listed, although Argentina, Brazil and Uruguay are all parties to the Convention. Both Argentina and Brazil are also parties to the Convention Concerning the Protection of World Cultural and Natural Heritage (World Heritage Convention [WHC]) (1972). All contracting countries are expected to take measures to protect their own resources and natural heritage. To date, no WHC sites with river dolphin populations have been established in South America. However, in October 2001, Argentina was elected to the World Heritage Committee, which may enable evaluation of the potential for WHC sites in the southern Atlantic Ocean. The Convention on the Conservation of Migratory Species of Wild Animals (CMS) (Bonn Convention) (1979), could likewise provide a mechanism for multinational efforts to protect the franciscana. Parties to the CMS are required to protect species by removing obstacles that may endanger them during migration across country boundaries. In 1997, the franciscana was listed in Appendix I of the CMS, which includes species considered to be in danger of extinction. It is currently the only small cetacean in southern South America listed in Appendix I. Although Brazil is not currently a party to the CMS, it can legally enter into a Memorandum of Understanding with party countries (Atkins, 1989). Despite the good intentions of these conventions, however, very little progress has actually been made on international marine mammal protection in the South Atlantic region.

\section{The Interviews}

The interviews for this study were carried out in the fishing villages of Las Toninas, Santa Teresita, La Lucila del Mar, San Bernardo and Mar de Ajó along the CSA, and in the city of Buenos Aires. In each location, the interviews focused on a representative group. The objectives were to: 1) establish baselines on the level of knowledge and attitudes towards the franciscana by local people; 2) investigate whether the suspected incidental take levels were indeed high in these small fishing villages; 3 ) gain an understanding of the socioeconomic dimensions of the artisanal fishery in the BAP, and 4) research the legal framework for marine resource protection in Argentina. From this information, recommendations emerged for mitigating entanglement and better marine mammal protection. Interviewees included sports fishermen, marine biologists, artisanal gillnet fishermen, government officials and officers of the Prefectura Naval Argentina (Argentine Coast Guard, ACG). Eight fishermen along the CSA between General Lavalle and Mar de Ajó, eight marine scientists from different institutions and four government officials (including the ACG officers) were interviewed. All interviews were conducted in Spanish and recorded with permission (Table 1). The interviews with fishermen were conducted over several days within the fishing villages along the CSA. Other interviews were carried out in Buenos Aires.

\section{Results}

Preliminary estimates from field surveys indicated there may be as many as 28 artisanal fishermen operating in that region alone, and 10 more between Mar de Ajó and Mar de las Pampas (Albareda and Albornoz, 1997; Cappozzo et al., 2000). The fishermen in this area use inflatable or fiberglass outboard motor vessels $4-5 \mathrm{~m}$ in length. The nets are anchored on the bottom, catching bottom-feeders including white croaker (Micropogonias furnieri), which are also prey for the franciscana (Rodriguez et al., 2002). They set 1-3 monofilament gillnets $35-150 \mathrm{~m}$ in length (1-3 panels, $35-50 \mathrm{~m}$ apiece strung together) and $2-2.8 \mathrm{~m}$ high, with a mesh size ranging from 7 to $14 \mathrm{~cm}$. These nets are retrieved 1 to 3 times a day, depending upon the season, catch amount, and number of tourists on the beach, who drives the demand for fresh fish. Each trip takes 2-3 hours. In March 1999, at the end of the summer season, the catch average was roughly 15 fish per panel per trip per boat, resulting in a daily average of approximately 45 with roughly 30 being commercially valuable. All marketable species are kept and sold unless they surpass the market demand.

The economics of the artisanal fishery are tenuous. At the time of this study, fishermen of the CSA were required to purchase licenses from the ACG to fish out of each village. However, under Resolution 4/2000 of the Federal Fishing Agency, fees have been suspended for the artisanal fleet, although new permits have continued to be issued. Fishermen invest in their own equipment and fuel. A net costs about US $\$ 300$ to purchase and US $\$ 100$ for each significant repair. As long as the fishermen only sell their catch on the beach at their own market stands, they do not

Table 1. Interview Chart.

\begin{tabular}{|l|l|}
\hline INTERVIEWEE & \multicolumn{1}{|c|}{ SUBJECT of INTERVIEW } \\
\hline Artisanal fishermen & Details of fishery, including incidental take levels; socioeconomic conditions \\
\hline Marine mammal scientists & Biology and management of the franciscana; issues of overfishing and bycatch \\
\hline Federal government officials & $\begin{array}{l}\text { Current legal framework for marine mammal protection; federal efforts underway for } \\
\text { marine mammal protection }\end{array}$ \\
\hline Coast Guard officials & Enforcement measures for marine mammals and fisheries \\
\hline
\end{tabular}


pay taxes. They receive no subsidy from the Argentine government. They can make as much as $\$ 300$ a day (US \$120) during the two best tourist and fishing months in the summer, but these figures are not sustained throughout the year, when the average daily gross income drops to approximately \$25 (US \$10) and the weather keeps them off the water more frequently. Until 2000, they were required to pay fees to obtain their permits.

The fishermen in this region reported bycatch levels of 1-2 franciscana per season, although one fisherman reported catching eight in a single day, and one reported 10 per season. These numbers are difficult to reconcile, but it is likely the higher quoted figures are more accurate. The fisherman who had caught the eight reported catching only 1-2 per season at another point in the interview. In general, the fishermen expressed concern about the franciscana mortality rates, but their immediate concerns were catch rates and gear loss from South American sea lion (Otaria flavescens) predation and overfishing.

The fishermen reported an increasing number of fishermen in the CSA over the last several seasons, including the presence of commercial coastal vessels fishing illegally inside the 3-mile coastal zone. Since 1997, pressure has continued, as more vessels continue to compete for fewer resources. In October of 1997 the Instituto Nacional de Investigación y Desarrollo Pesquero (INIDEP) [the National Institute of Fishery Research and Development] proposed a plan to develop the coastal fishery, including gillnetting, in the southern part of the BAP. In response to this increased pressure, the artisanal fishermen reported changes they had made in their individual fishing effort. Two relied on another source of income, two started fishing during the winter season, and two added longlines to their fishing gear. Most reported increasing the number of nets they used and days they fished. Fishermen who switched to fishing yearround sold their catch to markets in the towns during the winter. In general, they did not favor this arrangement, but were compelled to accept it given their financial circumstances. Their reluctance may partly have been due to the fact that sales conducted in the village markets were heavily taxed, and the fishermen collected a small percentage of the total price of the fish. In winter they alternated between gillnets and longlines. There were no reports of incidental franciscana take from the longlines.

The interviews with Argentine marine scientists revealed several overlapping conclusions. The scientists stated unanimously that efforts to protect the franciscana must be made on multiple levels and include all stakeholders: fishermen, scientists, ACG officials, Argentine government representatives and national and international NonGovernmental Organizations (NGOs). They concurred that local efforts must be combined with national and international support, and all involved parties should learn from the expertise of the others. They stressed the need to respect existing local cultural patterns. The scientists also commented that they often felt they were working at crosspurposes to, and without support from, the federal and provincial governments.
In the view of the scientists, overfishing and bycatch posed the most significant problems for the franciscana. They also felt that the economic situation in Argentina must be addressed. They reported that decisions are currently being made without regard for the long-term effects of overfishing and subsequent resource loss on the economy of Argentina. Lastly, the scientists stressed the importance of teaching local communities that they have both a responsibility and an economic incentive to protect their living marine resources for the future.

The Secretariat focused on the general issues of overfishing and marine mammal bycatch, stating that it was a global problem from which Argentina could not hope to escape. The Secretariat pointed to the current studies being done by Argentine marine biologists on the franciscana as evidence that progress was being made to protect the species. As well, the Secretariat described the unprecedented meeting convened in February 1999 between its representatives and the Federal Fisheries Council to gather information on marine mammal-fishery interactions in Argentina. The event marked the first occasion that an Argentine government agency official took the initiative to further the effort to implement a marine mammal incidental catch strategy. However, the report drafted for the meeting did not include the CSA area or the maritime artisanal fleet, and no legal or regulatory actions have been taken since its submission to the government.

The Secretariat also emphasized the importance of both the National Fishery Law 24.922 and Resolution 351/95 in addressing marine mammal protection. The Secretariat submitted that additional legislation was required to address both the management of the fishing industry and the issue of marine mammal bycatch. Lastly, the Secretariat stated that the development of a federal law regarding marine biological diversity should be promoted. The Secretariat deemed the national NGOs to be sufficient in addressing the concerns surrounding the franciscana.

The ACG officials reported that the majority of their resources were spent enforcing commercial fisheries regulations and combating illegal fishing by foreign and Argentine vessels. They also emphasized that there is no law for them to enforce with regard to marine mammal protection for species that are not being commercially exploited, which makes any effort on their side to reduce incidental take rates virtually impossible. Officials also said the agency did not receive sufficient resources from the federal or provincial governments to adequately perform its duties.

\section{Discussion}

The responses from the Secretariat illuminate several of the underlying problems in efforts to protect the franciscana, notably that the current legal framework is inadequate, and the belief that the research being undertaken and NGO support being given is sufficient, despite evidence to the contrary. Some officials at the federal level appear to be reluctant to act on research and management needs without the cooperation and financial support of the provincial secretaries. Others seem hesitant to make decisions without scientific evidence to back 
their actions, though they have not committed any funds for scientific research or made efforts to assist the national environmental NGOs in their work.

An important factor for marine stewardship in Argentina is the lack of legal and regulatory enforcement of the fishing industry. The Argentine government depends upon the ACG to regulate the fishing activities of the artisanal as well as commercial operations along the Argentine coast. However, the ACG works under extremely limited funds and often without access to necessary equipment. ACG officers have no enforcement power over the fishermen, despite their responsibility to monitor fishing activity. In contrast, the federal and provincial governments do have the necessary power of enforcement, but have not demonstrated an accompanying sense of responsibility. As the ACG receives little institutional support from the federal and provincial governments, it is unable to effectively monitor fishing activity and incidental take.

The law in Argentina designates the area inside the 3-mile radius from shore for maritime artisanal boats, and outside this boundary for larger vessels. Compliance regarding this regulation is low, however. Artisanal fishermen and scientists have witnessed vessels fishing illegally within the 3-mile zone off the Argentine shore for several years. This increased pressure closer to shore reduces available catch for artisanal fishermen, forcing them to increase effort. This intensification of effort by both the larger vessels and the maritime artisanal fleet is directly linked to an increase in the incidental take risk for the franciscana. In addition, the use of a smaller mesh size and more nets has resulted in lower catch rates and smaller fish, leading to a situation in which the franciscana and fishermen are in direct competition for certain fish species in the same habitat. Even in areas where the target and prey species are distinct, the reduction in biomass caused by the fishery may have effects on many species, including the franciscana (Crespo et al., 1997). Increased franciscana mortality is correlated to increased numbers of nets. It also appear to correspond with the summer calving season, when the franciscana spends more time closer to the shore and gillnet fishing areas (Bordino et al., 1999).

The fishermen who have staked out these areas close to shore have little interest in relinquishing their territory to reduce franciscana mortality. In the absence of effective regulation, education and a history of resource protection, short-term economic conditions - rather than sustainable resource management-have determined the course of action. None of the eight fishermen interviewed suggested fishing less to replenish depleting stocks. Results from the interviews suggest that the conservation status of the franciscana and other marine mammals will be addressed only after the amount of fish and money coming in is stable, and fishermen can be reassured that conservation measures will not jeopardize their ability to support themselves. The success of any conservation program will depend upon the cooperation among scientists, the artisanal fishermen who encounter the problem of incidental mortality on a regular basis, and the government officials who can provide the financial support needed to reduce bycatch.

International instruments have the potential to provide additional support for reducing incidental take rates. However, little progress has been made in the international arena. Fundamentally, it may be difficult for countries to develop an international management regime when they have not yet drafted national plans for marine mammal protection. Concomitant with this factor is the reality that there are no fora for policymakers and scientists to exchange information or discuss management strategies, even at the local level. Without strong, internal communication of this type, it is difficult to move forward at the international level. Lastly, these countries do not yet have a history of negotiating international marine environmental instruments or of co-managing marine resources.

\section{Conclusion}

In spite of the work and concern devoted to this issue over the last several years, data continue to reveal significant bycatch figures for the franciscana in artisanal fishing activities in Argentina. Although more study is needed in some areas, the current data are sufficient to warrant the response of regulatory and scientific bodies to respond on its behalf at the local, provincial, national and international level. Deliberate, prompt action to develop a conservation strategy must be taken to produce any significant change in the status of the franciscana dolphin. Toward this end, the recommendations below should be afforded immediate attention and funding. A concerted, coordinated effort is needed on multiple levels if Argentina is to reverse the current unsustainable use of its marine resources and endangerment of the franciscana.

\section{Recommendations}

At the Fourth Workshop for the Coordinated Research and Conservation of the Franciscana Dolphin (Pontoporia blainvillei) in the Western South Atlantic in 2000, several recommendations were made for continued field research (Secchi et al., 2002) that should be followed. The recommendations in this paper focus on the policy aspects of conservation for this species.

1) Create an adaptive managerial framework in which all perspectives are represented.

> Data, traditional knowledge, resources, and concerns of the artisanal fishermen should be incorporated into all studies and designs for solutions.

$>$ Collaboration should be encouraged, and supported through financial incentives if necessary, between scientists and artisanal fishermen in field studies that have the potential to reduce franciscana mortality.

- A current example of this partnership is the on-going pinger experiment in the CSA region. Most of the artisanal fishermen agreed to participate in a pinger experiment to reduce dolphin take rates. Results from the last three field seasons indicate that the use of pingers decreases incidental take rates, but an increase in sea lion 
predation on netted fish has been observed (Bordino et al., in press). Acoustic deterrents have shown positive results with cetaceans in other fisheries, including gillnet fisheries in New England (Kraus et al., 1997; Kraus, 1999). They are considered a potentially important and useful technology for reducing marine mammal bycatch in gear for some fisheries (Dawson, 1994).

- Fishermen should be encouraged to experiment with moving their net locations within their fishing areas, and alter their gear (switching to longlines, using pingers, and reducing net size). Gear modification is a standard recommendation in Take Reduction Plans (TRPs) and should be considered in this situation, although economic realities may preclude it as a permanent solution (AOCTRT, 1996; PCTRT, 1996; MATRT, 1997).

- Sea lion interactions should be addressed to encourage the cooperation and involvement of the artisanal fishermen, as sea lions are perceived to be a direct threat to the fishermen's economic stability.

$>$ Cooperative monitoring efforts between the government agencies and fishermen should be encouraged. This result can be encouraged through the provision of financial incentives to collaborate with local researchers on a monitoring regime for fishing effort and marine mammal bycatch levels.

> Policymakers and scientists should work together to coordinate their research and management objectives. While scientific and policy decisions should ultimately be kept separate, policymakers are more likely to make better decisions regarding marine mammal protection if they have the data they need from the scientific community, and scientists are more likely to be able to collect directly applicable data if they are aware of the needs of the policymakers.

2) Promote economic stability by encouraging income diversification, decreased reliance on fisheries, and market stabilization.

$>$ The Argentine government should develop an effective conservation strategy that involves careful consideration of the unique circumstances of the artisanal fishery and encourages economic stability. The strategy should include buying back vessels when appropriate, regulating the local markets, and enforcing fishing regulations.

- For example, it is not feasible to ask the artisanal fishermen to fish farther from the shore. In their small boats, it is dangerous for them to travel relatively long distances from the shore (i.e., few miles), they must spend more money on fuel, and they lose revenue being away from the beach for longer periods of time. On days with inclement weather, they make no money at all. Without the security of financial stability or fear of regulation, artisanal fishermen are unlikely to comply or cooperate with regulations. Greater stability can aide in reversing the current trend of noncompliance.

$>$ Fishermen interested in leaving the fishery could be provided with a one-time incentive package that is contingent upon a commitment not to re-enter. Such a package could include financial compensation in return for retiring a vessel, or could include training for a new profession. For those who continue to fish, financial or technical compensation could be provided if fishermen agree to accurately report the amount of catch and bycatch taken and collaborate with scientists on developing further take reduction strategies.

$>$ The long-term goal may be to incorporate the artisanal fishermen into the economic system, requiring abidance with the fishing regulations and tax payments in return for economic stability, perhaps in the form of greater control of market pricing and the percentage received by the artisanal fishermen or assistance in income diversification. No incentive currently exists for the artisanal fishermen to enter into any management regime.

3) Undertake an education campaign on marine conservation and outreach campaign on fishing alternatives and sustainable fishing practices.

> Educating the local communities about the franciscana is likely to be essential for developing the political and societal will to protect it. Knowledge and understanding can often lead to a sense of pride and ownership (AOCTRT, 1996; MATRT, 1997). If local communities, and the artisanal fishermen in particular, are made aware that the franciscana is a rare dolphin species, it may engender in them a sense of stewardship, and prompt them to take measures to protect it. Perhaps more importantly, if fishermen know that these concrete measures will not force them to sacrifice their own livelihoods, they may be that much more willing to help protect it. Finally, an informed citizenry is more likely to support new legislation or improvements to existing legislation to protect living marine resources.

$>$ Fishermen may benefit from learning about take reduction strategies and economically viable alternatives to fishing. The Argentine government, scientists, and NGOs should inform the fishermen about the existence of gear alternatives and other fishing modifications. These modifications could be introduced into the artisanal fishing community through meetings, workshops, newsletters, technical training sessions, or other mechanisms, depending upon the wishes of the local fishing communities.

$>$ Schools and the media should focus on educating and informing the public on species conservation, the effects of overfishing, and ecosystem-based management. This effort could include a campaign highlighting commercial species, so that consumers know how species are connected to marine ecosystems, and what pressures fishing places on marine mammals, and the franciscana in particular.

> Policymakers should be informed about the franciscana and marine mammals in Argentina. The current legislative language is not sufficient for addressing the majority of the threats to marine mammals, and attempts to enact more should be encouraged.

4) Encourage cooperation and coordination at the international level among government officials to share information and adopt a management regime.

$>$ Policymakers from each of the federal governments of Argentina, Brazil and Uruguay should be brought into the 
scientific discussions and conferences that already exist for marine mammals and the franciscana in particular.

- The scientific track and the policy track should be moving forward along parallel lines, so that there are policy changes that have been studied and can be made once new data emerge about threats to the species or its status.

- Governments should devote resources to establishing international regimes for the protection of overlapping waters and cross-boundary marine mammal species. Argentina, Brazil and Uruguay can negotiate a legal instrument using existing international structures such as the CMS, because the species is already listed.

$>$ Protected areas should be established. In addition to providing protection for the franciscana, this effort has the potential to benefit other coastal species and habitats, including white croaker (Micropogonias furnieri), the Burmeister's porpoise (Phocoena spinnipinnis), and various migratory shorebirds. International technical and monetary support may be available for these efforts - particularly when the identified areas cross national boundaries through the United Nations Educational, Scientific and Cultural Organization (UNESCO) World Heritage Site program.

- Studies should be undertaken to determine where areas of critical habitat are located for the franciscana.

- Once these geographic areas are identified, a carefully designed implementation process should be undertaken that includes solicitating input from all stakeholders.

- Ultimately, these areas should be protected from potentially detrimental activities, including gillnet fishing, shipping, and activities increasing the pollution runoff from the land connected to the critical marine habitat.

- Managers should be detailed to protected areas, existing reserves and fishing communities to strengthen enforcement efforts and provide a strong resource management presence.

\section{Acknowledgments}

The authors would like to thank each of the following people and institutions, without whose generous assistance this study could not have been completed: the Argentine Coast Guard (both the Division of Environmental Protection and the Sub Prefectura Carmen de Patagones, Destacamento San Blas); the Department of Fish and Aquatic Resources under the Secretariat of Natural Resources and Sustainable Development in the Argentine government; the artisanal fishermen of Las Toninas, Santa Teresita, La Lucila del Mar, San Bernardo and Mar de Ajó; Diego A. Albareda; Kenneth C. Baldwin; Hugo P. Castello and the Argentine Museum of Natural Sciences; Enrique A. Crespo; Gustavo A. Thompson and Alejandra Volpedo. In addition, the authors would like to extend their sincere gratitude to Gary M. Tabor and the Center for Conservation Medicine, Tufts University School of Veterinary Medicine; Gary J. Patronek, Michele
Goldsmith and the Center for Animals and Public Policy, Tufts University School of Veterinary Medicine; William W. Rossiter and the Cetacean Society International; Scott D. Kraus and the New England Aquarium, and Wildlife Trust for financial and technical support. Randall R. Reeves; Sharon B. Young; John R. Twiss, Jr.; the U.S. Marine Mammal Commission and the Editor provided helpful comments on early drafts of this paper. Thank you lastly to Brian Smith; Ricardo Bastida; Diego Rodriguez and an anonymous referee for additional critical feedback.

\section{References}

Albareda, D.A. and Albornoz, N. (1997) Mortalidad de franciscanas en la pesqueria artesanal de San Bernardo y Mar de Ajó, Provincia de Buenos Aires, Argentina. Pages 54-61 in Pinedo, M.C. and Barreto, A.S. (Eds) Anais do $2^{\circ}$. Encontro sobre a Coordenação de Pesquisa e Manejamento da Franciscana. Ed. FURG, Rio Grande.

Atlantic Offshore Cetaceans Take Reduction Team (AOCTRT). (1996) Atlantic Offshore Cetaceans Take Reduction Plan. Report held at National Marine Fisheries Service, Silver Spring, MD. Contract No. 50-DGNF-5-00164. 66pp.

Atkins, N. (1989) Summary of national laws and international agreements affecting river dolphins. Pages 168-173 in Perrin, W.F., Brownell Jr., R.L., Zhou, K. and Liu, J. (Eds) Biology and Conservation of the River Dolphins. Occas. pap. IUCNSSC 3. Gland.

Bordino, P., Kraus, S., Albareda, D., Baldwin, K., Fazio, A., Palmerio, A., Mendez, M. and Botta, S. (in press) Use of acoustic alarms to reduce the bycatch of franciscana Pontoporia blainvillei in gillnets. Marine Mammal Science.

Bordino, P., Thompson, G. and Iñíguez, M. (1999) Ecology and behavior of the franciscana (Pontoporia blainvillei) in Bahía Anegada, Argentina. Journal of Cetacean Research and Management 1(2): 213-222.

Brownell Jr., R.L. (1989) Franciscana, Pontoporia blainvillei (Gervais and d'Orbigny 1844). Pages 45-67 in Ridgway, S.H and Harrison, R.J. (Eds) Handbook of Marine Mammals vol4. Academic Press, London.

Brownell Jr., R.L. and Ness, R. (1970) Preliminary Notes on the Biology of the franciscana, Pontoporia blainvillei (Cetacea: Platanistidae). Proc. Sixth Annual Conference Biological Sonar and Diving Mammals - 1969. Pages 23-26. Stanford Research Institute, Menlo Park.

Cappozzo, L.H., Monzón, F., Perez, J.E., Albareda, D. and Corcuera, J. (2000) Mortalidad del defin franciscana, Pontoporia blainvillei, en la Provincia Buenos Aires. Technical Paper WP24 presented to the IV Workshop para a Coordenação da Pesquisa e Conservação da Franciscana, Pontoporia blainvillei, no Atlântico Sul Ocidental. 05-09 November, Porto Alegre.

Corcuera, J. (1994) Incidental mortality of franciscanas in Argentine waters: The threat of small fishing camps. Pages 291-294 in Perrin, W.F., Donovan, G.P. and Barlow, J. (Eds) Gillnets and Cetaceans. Reports of the International Whaling Commission (Special Issue 15).

Corcuera, J., Monzón, F., Crespo, E.A., Aguilar, A. and Raga, J.A. (1994) Interactions between marine mammals and the coastal fisheries of Necochea and Claromecó (Buenos Aires Province, Argentina). Pages 283-290 in Perrin, W.F., Donovan, G.P. and Barlow, J. (Eds) Gillnets and Cetaceans. Reports of the International Whaling Commission (Special Issue 15).

Corcuera, J., Monzón, F., Pérez, J., Beilis, A., Gingarelli, M., Albareda, D., Cornejo, I. and Arias, A. (2000) Mortalidad de Pontoporia blainvillei en el norte de la provincia de Buenos Aires. Pages 75-80 in UNEP/CMS (Eds) Report of the Third Workshop for Coordinated Research and Conservation of the Franciscana Dolphin (Pontoporia blainvillei) in the Southwestern Atlantic. UNEP/CMS, Bonn. 
Crespo, E.A., Corcuera, J. and Cazorla, A.L. (1994) Interactions between marine mammals and fisheries in some coastal fishing areas of Argentina. Pages 269-281 in Perrin, W.F., Donovan, G.P. and Barlow, J. (Eds) Gillnets and Cetaceans. Reports of the International Whaling Commission (Special Issue 15).

Crespo, E.A., Pedraza, S.N., Dans, S.L., Koen Alonso, M., Reyes, L.M., Garcia, N.A., Coscarella, M. and Schiavini, A.C.M. (1997) Direct and indirect effects of the highseas fisheries on the marine mammal populations in the northern and central Patagonian coast. Journal of Northwest Atlantic Fishery Science (22): 189-207.

Crespo, E.A., Harris, G. and González, R. (1998) Group size and distributional range of the franciscana, Pontoporia blainvillei. Marine Mammal Science 14: 845-849.

Dawson, S.M. (1994) The potential for reducing entanglement of dolphins and porpoises with acoustic modifications to gillnets. Pages 573-578 in Perrin, W.F., Donovan, G.P. and Barlow, J. (Eds) Gillnets and Cetaceans. Reports of the International Whaling Commission (Special Issue 15).

Hucke-Gaete, R. (Ed.) (2000) Review of the Conservation Status of Small Cetaceans in Southern South America. UNEP/CMS Secretariat, Bonn, Germany. 24pp.

International Whaling Commission. (1994) Report of the Workshop on Mortality of Cetaceans in Passive Fishing Nets and Traps in Perrin, W.F., Donovan, G.P. and Barlow, J. (Eds) Gillnets and Cetaceans. Reports of the IWC. Special Issue 15: v-vi and 6-71.

Kasuya, T. and Brownell, R.L. (1979) Age determination, reproduction and growth of franciscana dolphin, Pontoporia blainvillei. Scientific Reports of the Whales Research Institute 31: 45-67.

Kraus, S.D. (1999) The once and future ping: Challenges for the use of acoustic deterrents in fisheries. Marine Technological Society Journal 33(2): 90-93.

Kraus, S.D., Read, A., Anderson, E., Baldwin, K., Solow, A., Spradlin, T. and Williamson, J. (1997) Acoustic alarms reduce porpoise mortality. Nature 388: 525.

Mid-Atlantic Take Reduction Team (MATRT). (1997) Mid-Atlantic Take Reduction Team Management and Research Recommendations for Reducing Bycatch of Harbor Porpoise (Phocoena phocoena) in the Mid-Atlantic Gillnet Fisheries. Report held at National Marine Fisheries Service, Silver Spring, MD. 22pp.

Pacific Cetacean Take Reduction Team (PCTRT). (1996) Pacific Cetacean Take Reduction Plan. Report held at National Marine Fisheries Service, Silver Spring, MD. 75pp.

Pérez Macri, G. and Crespo, E.A. (1989) Survey of the franciscana, Pontoporia blainvillei, along the Argentine coast, with a preliminary evaluation of mortality in coastal fisheries. Pages 57-63 in Perrin, W.F., Brownell Jr., R.L., Zhou, K. and Liu, J. (Eds) Biology and Conservation of the River Dolphins. Occas. pap. IUCN SSC 3.

Perrin, W.F. and Brownell Jr., R.L. (1989) Report of the Workshop. Pages 1-11 in Perrin, W.F., Brownell Jr., R.L., Zhou, K. and Liu, J. (Eds) Biology and Conservation of the River Dolphins. Occas. pap. IUCNSSC 3.

Perrin, W.F., Donovan, G.P. and Barlow, J. (1994) Report of the Workshop on Mortality of Cetaceans in Passive Fishing Nets and Traps. Pages 6-71 in Perrin, W.F., Donovan, G.P. and Barlow, J. (Eds) Gillnets and Cetaceans. Reports of the International Whaling Commission (Special Issue 15).

Pinedo, M.C. (1991) Development and variation of the franciscana Pontoporia blainvillei. Doctoral Thesis, University of California, Santa Cruz. 406pp.

Pinedo, M.C., Praderi, R. and Brownell Jr., R.L. (1989) Review of the Biology and Status of the Franciscana, Pontoporia blainvillei. Pages
46-51 in Perrin, W.F., Brownell Jr., R.L., Kaiya, Z. and Jiankang, L. (Eds) Biology and Conservation of the River Dolphins. Occasional Papers IUCN, 3. Gland.

Praderi, R. (1984) Mortalidad de franciscana, Pontoporia blainvillei, en pesquerías artesanales de tiburón en la costa atlántica uruguaya. Revista del Museo Argentino de Ciencias Naturales "Bernardino Rivadavia", Zoología XIII: 259-272.

Praderi, R. (2000) Estado actual de la mortalidad de franciscana en las pesquerías artesanales de Uruguay. Pages 13-15 in UNEP/ CMS (Eds) Report of the Third Workshop for Coordinated Research and Conservation of the Franciscana Dolphin (Pontoporia blainvillei) in the Southwestern Atlantic. UNEP/CMS, Bonn.

Praderi, R., Pinedo, M.C. and Crespo, E.A. (1989) Conservation and management of Pontoporia blainvillei in Uruguay, Brazil and Argentina. Pages 52-55 in Perrin, W.F., Brownell Jr., R.L., Zhou, K. and Liu, J. (Eds) Biology and Conservation of the River Dolphins . Occas. pap. IUCN SSC 3. Gland.

Ramos, R., Di Beneditto, A.P.M. and Lima, N.R.W. (2000) Growth parameters of Pontoporia blainvillei in northern Rio de Janeiro, Brazil. Aquatic Mammals 26.1: 65-75.

Reeves, R.R. and Leatherwood, S. (Eds) (1994) Dolphins, Porpoises and Whales: 1994-1998 Action Plan for the Conservation of Cetaceans. IUCN SSC. 91pp.

Rodríguez, D., Rivero, L. and Bastida, R. (2002) Feeding ecology of the franciscana (Pontoporia blainvillei) in marine and estuarine waters of Argentina. The Latin American Journal of Aquatic Mammals (special issue) 1: 77-94.

Secchi, E.R., Zerbini, A.N., Bassoi, M., Dalla Rosa, L., Moller, L.M. and Roccha-Campos, C.C. (1997) Mortality of franciscanas, Pontoporia blainvillei, in coastal gillnetting in Southern Brazil: 1994-1995. Reports of the International Whaling Commission 47: 653-658.

Secchi, E.R., Wang, J.Y., Murray, B., Rocha-Campos, C.C. and White, B.N. (1998) Populational differences between franciscanas, Pontoporia blainvillei, from two geographical locations as indicated by sequences of mtDNA control region. Canadian Journal of Zoology 76: 1622-1627.

Secchi, E.R., Ott, P.H., Crespo, E.A., Kinas, P.G., Pedraza, S.N. and Bordino, P. (2001) A first estimate of franciscana (Pontoporia blainvillei) abundance off southern Brazil. Journal of Cetacean Research and Management 3: 95-100.

Secchi, E.R., Ott, P.H., Danilewicz, D. (2002) Report of the Fourth Workshop for the Coordinated Research and Conservation of the Franciscana Dolphin (Pontoporia blainvillei) in the Western South Atlantic. The Latin American Journal of Aquatic Mammals (special issue) 1: 11-20.

Secchi, E.R., Ott, P.H. and Danilewicz, D.S. (in press a) Effects of fishing by-catch and conservation status of the franciscana dolphin, Pontoporia blainvillei in Gales, N., Hindell, M. and Kirkwood, R. (Eds) Marine mammals and humans: towards a sustainable balance. Melbourne University Press, Melbourne.

Secchi, E.R., Danilewicz, D., and Ott, P.H. (in press $b$ ) Applying the phylogeographic concept to identify franciscana dolphin stocks: implications to meet management objectives. Journal of Cetacean Research and Management.

Siciliano, S. (1994) Review of small cetaceans and fishery interactions in coastal waters of Brazil. Pages 241-250 in Perrin, W.F., Donovan, G.P. and Barlow, J. (Eds) Gillnets and Cetaceans. Reports of the International Whaling Commission (Special Issue 15).

World Conservation Union (IUCN). (2000) The IUCN Species Survival Commission 2000 Red List of Threatened Species. Gland. 